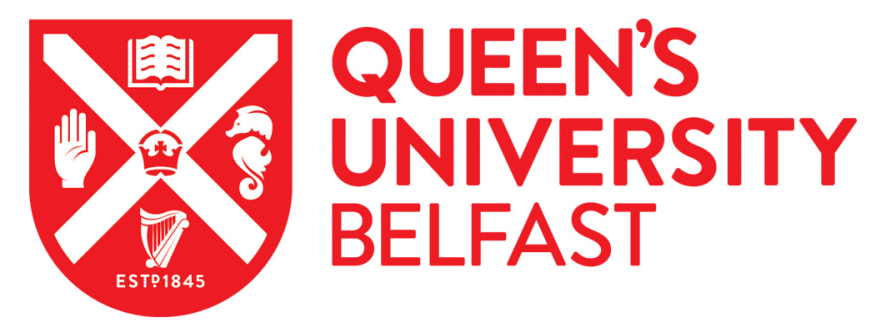

\title{
Effect of precursor on the performance of alumina for the dehydration of methanol to dimethyl ether
}

Osman Ahmed, A., Abu-Dahrieh, J. K., Rooney, D. W., Halawy, S. A., Mohamed, A. M., Abdelkader, A., \& AbuDahrieh, J. (2012). Effect of precursor on the performance of alumina for the dehydration of methanol to dimethyl ether. Applied Catalysis B: Environmental, 127, 307-315. https://doi.org/10.1016/j.apcatb.2012.08.033

Published in:

Applied Catalysis B: Environmental

Document Version:

Peer reviewed version

Queen's University Belfast - Research Portal:

Link to publication record in Queen's University Belfast Research Portal

\section{Publisher rights}

This is the author's version of a work that was accepted for publication in Applied Catalysis B: Environmental. Changes resulting from the publishing process, such as peer review, editing, corrections, structural formatting, and other quality control mechanisms may not be reflected in this document. Changes may have been made to this work since it was submitted for publication. A definitive version was subsequently published in Applied Catalysis B: Environmental, VOL 127, 30/10/2012

\section{General rights}

Copyright for the publications made accessible via the Queen's University Belfast Research Portal is retained by the author(s) and / or other copyright owners and it is a condition of accessing these publications that users recognise and abide by the legal requirements associated with these rights.

Take down policy

The Research Portal is Queen's institutional repository that provides access to Queen's research output. Every effort has been made to ensure that content in the Research Portal does not infringe any person's rights, or applicable UK laws. If you discover content in the Research Portal that you believe breaches copyright or violates any law, please contact openaccess@qub.ac.uk. 


\section{Accepted Manuscript}

Title: Effect of Precursor on the Performance of Alumina for the Dehydration of Methanol to Dimethyl Ether

Authors: Ahmed I. Osman, Jehad K. Abu-Dahrieh, David W. Rooney, Samih A. Halawy, Mohamed A. Mohamed, Adel Abdelkader

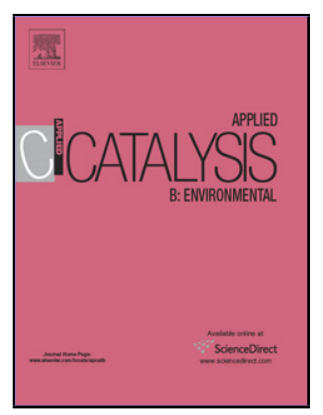

PII: S0926-3373(12)00391-8

DOI:

Reference: doi:10.1016/j.apcatb.2012.08.033

To appear in: APCATB 12213

Received date: Applied Catalysis B: Environmental

Revised date:

$21-6-2012$

Accepted date:

$7-8-2012$

28-8-2012

Please cite this article as: A.I. Osman, J.K. Abu-Dahrieh, D.W. Rooney, S.A. Halawy, M.A. Mohamed, A. Abdelkader, Effect of Precursor on the Performance of Alumina for the Dehydration of Methanol to Dimethyl Ether, Applied Catalysis B, Environmental (2010), doi:10.1016/j.apcatb.2012.08.033

This is a PDF file of an unedited manuscript that has been accepted for publication. As a service to our customers we are providing this early version of the manuscript. The manuscript will undergo copyediting, typesetting, and review of the resulting proof before it is published in its final form. Please note that during the production process errors may be discovered which could affect the content, and all legal disclaimers that apply to the journal pertain. 


\section{Graphical Abstract}
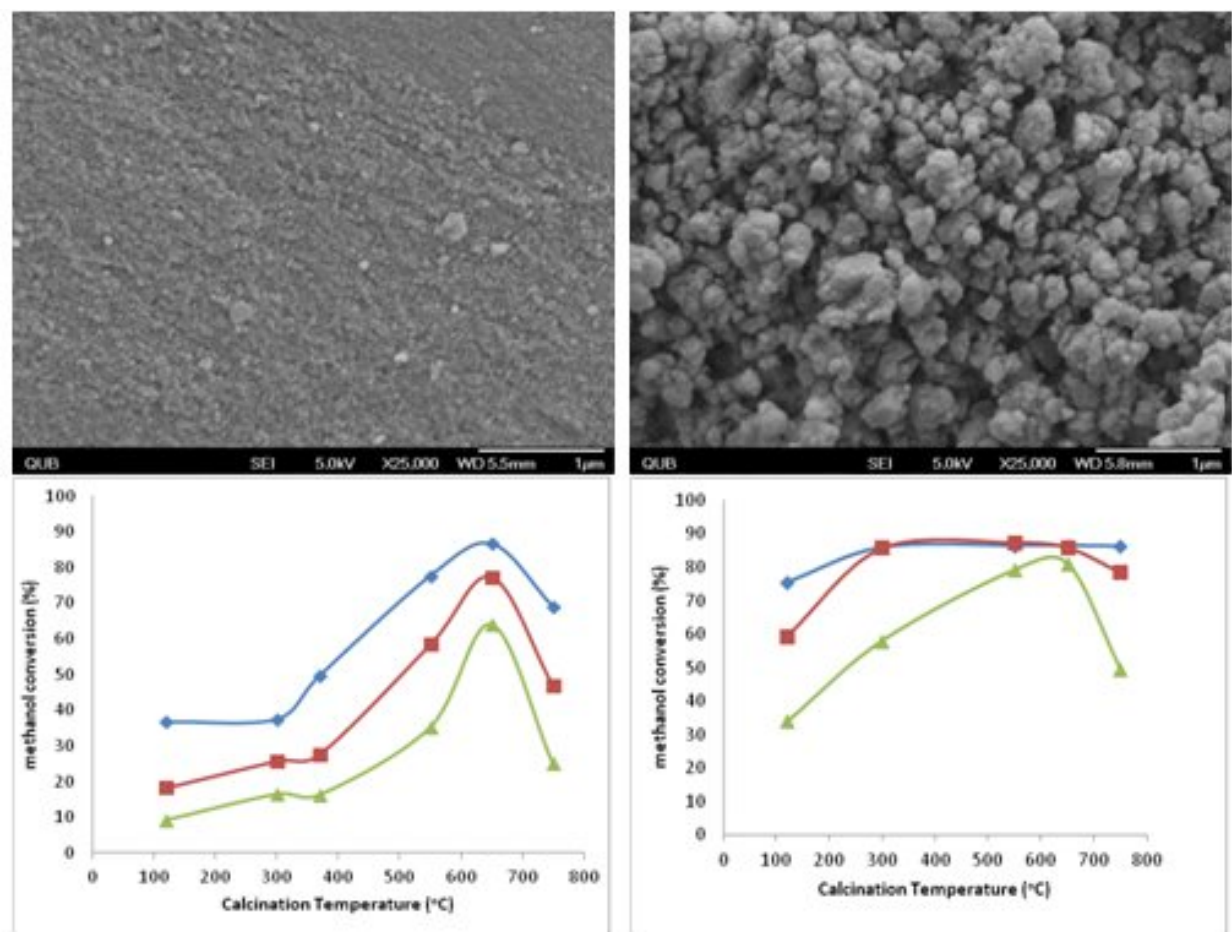


\section{Highlights}

- Effect of precursors on the catalytic performance of alumina.

- AN samples is higher activity than AC, while AN550 is the optimum one.

- The AN550 showed methanol conversion and DME selectivity of $72 \%$ and $100 \%$ at $250{ }^{\circ} \mathrm{C}$, respectively.

- Acid site density affected catalytic performance among the catalysts with alumina phase.

- Synthesis of alumina catalyst with high activity compared to commercial $\mathrm{\gamma}-\mathrm{Al}_{2} \mathrm{O}_{3}$. 
Effect of Precursor on the Performance of Alumina for the Dehydration of Methanol to

\title{
Dimethyl Ether
}

\author{
Ahmed I. Osman ${ }^{\mathrm{a}, \mathrm{b}}$, Jehad K. Abu-Dahrieh ${ }^{\mathrm{a}}$, David W. Rooney ${ }^{\mathrm{a}^{*}}$, Samih A. Halawy, \\ Mohamed A. Mohamed ${ }^{\mathrm{b}}$, Adel Abdelkader ${ }^{\mathrm{b}}$
}

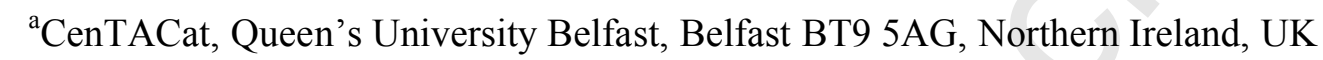
${ }^{\mathrm{b}}$ Chemistry Department, Faculty of Science - Qena, South Valley University, Qena 83523 - Egypt.

* Corresponding author

David Rooney

E-mail: d.rooney@qub.ac.uk

Address: School of Chemistry and Chemical Engineering, Queen's University Belfast, David Keir Building, Stranmillis Road, Belfast BT9 5AG, Northern Ireland, United Kingdom

Fax: +442890974687

Tel.: +442890974050 


\begin{abstract}
Dimethyl ether (DME) is amongst one of the most promising alternative, renewable and clean fuels being considered as a future energy carrier. In this study, the comparative catalytic performance of $\gamma-\mathrm{Al}_{2} \mathrm{O}_{3}$ prepared from two common precursors (aluminium nitrate (AN) and aluminium chloride (AC)) is presented. The impact of calcination temperature was evaluated in order to optimise both the precursor and pre-treatment conditions for the production of DME from methanol in a fixed bed reactor. The catalysts were characterized by TGA, XRD, BET and TPD-pyridine. Under reaction conditions where the temperature ranged from 180$300{ }^{\circ} \mathrm{C}$ with a WHSV $=12.1 \mathrm{~h}^{-1}$ it was found that all the catalysts prepared from $\mathrm{AN}\left(\eta-\mathrm{Al}_{2} \mathrm{O}_{3}\right)$ showed higher activity, at all calcination temperatures, than those prepared from $\mathrm{AC}(\gamma-$ $\mathrm{Al}_{2} \mathrm{O}_{3}$ ). In this study the optimum catalyst was produced from $\mathrm{AN}$ and calcined at $550{ }^{\circ} \mathrm{C}$. This catalyst showed a high degree of stability and had double the activity of the commercial $\gamma-\mathrm{Al}_{2} \mathrm{O}_{3}$ or $87 \%$ of the activity of commercial ZSM-5 (80) at $250{ }^{\circ} \mathrm{C}$.
\end{abstract}

Keywords: DME, Methanol dehydration, acid catalyst, $\eta-\mathrm{Al}_{2} \mathrm{O}_{3}, \gamma-\mathrm{Al}_{2} \mathrm{O}_{3}$. 


\section{Introduction}

A growing awareness of climate change, air pollution and energy consumption necessitates the development of clean, renewable and sustainable fuels. In terms of small energy generators for either fixed or mobile power sources there are a number of existing technologies, of which diesel engines are common. However, unless legislated against, such engines produce exhaust streams with significant amounts of $\mathrm{NO}_{\mathrm{x}}, \mathrm{SO}_{\mathrm{x}}$ and particulates. Furthermore diesel exhausts have been linked to cancer [1] in a recent World Health Organisation report, thus clean alternatives are again desired [2]. Dimethyl ether (DME) is one of the most promising ultra clean, renewable and oxygenated alternative fuel for diesel engines. The reasons for this are numerous and include its lower auto-ignition temperature (cetane number, $\mathrm{CN}>55$ ), higher oxygen content ( $34.8 \%$ by mass) and $\mathrm{C}-\mathrm{O}-\mathrm{C}$ molecular structure. DME can be easily evaporated [3] is non-toxic, non-carcinogenic and noncorrosive. It is also considered as an environmentally friendly compound because of its low global warming potential over both short and long time horizons [4].

There are two main ways to produce DME, either by methanol dehydration over a solid acid catalyst or direct synthesis from synthesis gas over hybrid catalysts comprising metal oxide (i.e. Methanol synthesis) and a solid acid (i.e. Methanol Dehydration). Both of these reactions are shown below [5]

$$
\begin{aligned}
& 3 \mathrm{CO}+3 \mathrm{H}_{2} \leftrightarrow \mathrm{CH}_{3} \mathrm{OCH}_{3}+\mathrm{CO}_{2} \\
& 2 \mathrm{CH}_{3} \mathrm{OH} \leftrightarrow \mathrm{CH}_{3} \mathrm{OCH}_{3}+\mathrm{H}_{2} \mathrm{O}
\end{aligned}
$$

Methanol to DME (MTD) dehydration over a solid acid catalyst in a fixed bed reactor was first reported by Mobil in 1965. Since then, many methanol dehydration catalysts have been 
examined [5] including $\gamma-\mathrm{Al}_{2} \mathrm{O}_{3}[2,6-9]$, crystalline aluminosilicates $[9,10]$, zeolites (ZSM5) [11], clays [12] and phosphates such as aluminium phosphate [13, 14]. However the most common catalysts used are $\gamma-\mathrm{Al}_{2} \mathrm{O}_{3}$ and zeolites.

The activity of H-type zeolites has been reported for the dehydration of methanol to DME [15-19]. These zeolites are characterized by their high acidity, however, such high acidity can result in significant coke formation and consequently fast deactivation [20]. Furthermore methanol can undergo secondary reactions to produce hydrocarbons at temperatures higher than $240{ }^{\circ} \mathrm{C}[16]$. Coke deposition on the surface of catalysts has been observed in the case of strong acid catalysts $[2,21,22]$, and thus formation of coke as side product was reported as a disadvantage of using zeolites in MTD reaction. However, $\gamma-\mathrm{Al}_{2} \mathrm{O}_{3}$ has a low activity at temperatures lower than $300{ }^{\circ} \mathrm{C}$ were no hydrocarbons are formed thus giving a total selectivity for DME of $100 \%[16]$. Also $\gamma-\mathrm{Al}_{2} \mathrm{O}_{3}$ is associated with weak to medium acidic sites, and thus is preferable in the MTD reaction [14] providing greater coke stability and lower by-product formation [8].

Alumina is one of the most important structural materials with several transition phases that have enormous technological and industrial significance [23]. It is thus the most common catalyst and catalyst support used in heterogeneous catalysis due to its low cost, good thermal stability, high specific surface area, surface acidity and interaction with deposited transitional metals [24]. The $\gamma$-phase in particular is one of the polymorphic phases of alumina with numerous applications [23]. Alumina exists in eight different polymorphs - seven metastable phases $(\gamma, \kappa, \rho, \eta, \theta$ and $\chi)$ as well as the thermally stable $\alpha$-phase. The metastable (also known as transition) phases of alumina are intrinsically nanocrystalline in nature and 
can be easily synthesized by a variety of methods. $\gamma-\mathrm{Al}_{2} \mathrm{O}_{3}$ can be transformed into a different phase under heat treatment with this transformation sequence being illustrated as follows:[25]

$\gamma-\mathrm{Al}_{2} \mathrm{O}_{3} \stackrel{750^{\circ} \mathrm{C}}{\longrightarrow} \delta \stackrel{900^{\circ} \mathrm{C}}{\longrightarrow} \theta \stackrel{1200^{\circ} \mathrm{C}}{\longrightarrow} \alpha$

Boehmite, aluminium oxyhydroxide $(\mathrm{AlO}(\mathrm{OH}))$, is a versatile material employed in domains such as sol-gel ceramics, surface coatings, rheology control, and pharmaceuticals [26]. It is also an important precursor in preparing alumina. $\gamma-\mathrm{Al}_{2} \mathrm{O}_{3}$, is commonly produced from boehmite by calcination at $500^{\circ} \mathrm{C}$ in air [26], and those modified with silica, phosphorus or $\mathrm{B}_{2} \mathrm{O}_{3}$ are current commercial catalysts for the dehydration of methanol to DME [26].

Seo et al. [27] studied the influence of structure type of $\mathrm{Al}_{2} \mathrm{O}_{3}$ on the dehydration of methanol to dimethyl ether. Catalysts $\left(\gamma-\mathrm{Al}_{2} \mathrm{O}_{3}\right.$ and $\left.\eta-\mathrm{Al}_{2} \mathrm{O}_{3}\right)$ were prepared from boehmite and bayerite, respectively, via calcination at various temperatures and the effect of alumina properties on the catalytic performance evaluated. In their study it was noted that with heat treatment, the properties of alumina changed significantly. For example it was identified that the particle size of $\gamma-\mathrm{Al}_{2} \mathrm{O}_{3}$ increased with increasing calcination temperature while the total amount of acidic sites over $\gamma-\mathrm{Al}_{2} \mathrm{O}_{3}$ decreased. It was reported that the total acidity of alumina calcined at $400{ }^{\circ} \mathrm{C}$ (which was shown by XRD to be composed of $\gamma-\mathrm{Al}_{2} \mathrm{O}_{3}+$ boehmite phases) was $80.6 \pm 2.2 \mu \mathrm{mol} / \mathrm{g}$ while $\gamma-\mathrm{Al}_{2} \mathrm{O}_{3}$ calcined at $500{ }^{\circ} \mathrm{C}$ was $67.7 \pm 0.00 \mu$ mol- $\mathrm{NH}_{3} / \mathrm{g}$ catalyst. 
Transition aluminas are widely used as catalysts and catalyst supports in many industrial processes, in particular those related to petroleum refining [29]. Knözinger and Ratnasamy [29] studied the nature of aluminas and they proposed models for it. They reported that the nature of the surface hydroxyl on $\gamma-\mathrm{Al}_{2} \mathrm{O}_{3}$ depend on the surface microstructure and therefore differed on each crystal plane.

Clearly the preparation method affects the activity of the catalysts as activity varies with both precursor type and the preparation procedure. For alumina there are a number of different preparation methods which can be used. For example $\gamma-\mathrm{Al}_{2} \mathrm{O}_{3}$ can be prepared from different precursors as aluminium nitrate [2, 30], aluminium chloride [23, 31] or from aluminium isopropoxide $[6,8,26]$. In this work a comparative study was performed between the two cheapest and most readily available precursors which are aluminium nitrate and aluminium chloride. This was in order to identify which one was the best at producing an active catalyst with latter tests conducted to benchmark them against commercial materials. The effect of calcination temperature was also studied to find a catalyst with the highest catalytic performance for methanol dehydration to DME. Long term stability tests were also performed for the best active catalysts identified and again these were benchmarked against commercial materials.

\section{Experimental}




\subsection{Materials and methods}

The chemicals used in the present study were all analytical grade and supplied by Aldrich, UK. These included aluminium nitrate nonahydrate $\left[\mathrm{Al}\left(\mathrm{NO}_{3}\right)_{3} \cdot 9 \mathrm{H}_{2} \mathrm{O}\right]$, ammonia solution $(35 \%)$ and aluminium chloride anhydride $\left(\mathrm{AlCl}_{3}\right)$.

\subsection{Catalyst preparation}

Catalysts were prepared from two precursors namely $\mathrm{Al}\left(\mathrm{NO}_{3}\right)_{3} \cdot 9 \mathrm{H}_{2} \mathrm{O}$ and $\mathrm{AlCl}_{3}$. $\mathrm{Al}$ $\left(\mathrm{NO}_{3}\right)_{3} .9 \mathrm{H}_{2} \mathrm{O}$ was first dissolved in deionized water with continuous stirring at $60{ }^{\circ} \mathrm{C}$. When the solution was completely mixed and heated to $100^{\circ} \mathrm{C}$, ammonia solution was added dropwise. After the addition of the ammonia solution was completed stirring continued for a further $12 \mathrm{hrs}$ at room temperature (approx. $18^{\circ} \mathrm{C}$ ). The pale off-white precipitate was filtered, washed, and dried at $120{ }^{\circ} \mathrm{C}$ overnight. The precipitate was then calcined at either 300 or $550{ }^{\circ} \mathrm{C}$ for $4 \mathrm{~h}$. The catalysts that dried at $120{ }^{\circ} \mathrm{C}$ and those calcined at $300,550{ }^{\circ} \mathrm{C}$ are designated as AN120, AN300 and AN550, respectively.

The same procedure was followed for the catalysts prepared from the $\mathrm{AlCl}_{3}$ precursor. In this case and after filtration of the precipitate, the powders were thoroughly washed with hot water to remove any soluble chloride. The removal of chlorine was verified by a $\mathrm{AgNO}_{3}$ test. Here a sample of the filtrate was taken and a drop silver nitrate added, if this formed a precipitate or turbid solution would indicate the presence of chorine in the sample. In this case detectable levels of chlorine were not found. After drying at $120{ }^{\circ} \mathrm{C}$ overnight, the precipitate was calcined at $300,370,550,650$ and $750{ }^{\circ} \mathrm{C}$, respectively. As above the catalysts that were dried at 120 and calcined at $300,370,550,650$ and $750{ }^{\circ} \mathrm{C}$ are designated as AC120, AC300, AC370, AC550, AC650 and AC750, respectively. All the catalysts (dried 
and calcined) were further tested for chlorine content using Oxygen Flask analysis discussed below.

The commercial $\gamma-\mathrm{Al}_{2} \mathrm{O}_{3}\left(\mathrm{BET}=117 \mathrm{~m}^{2} / \mathrm{g}\right)$ was prepared by crushing $\gamma-\mathrm{Al}_{2} \mathrm{O}_{3}$ pellets (Alfa Aesar). Commercial $\mathrm{NH}_{4}-\mathrm{ZSM}-5$ zeolite (Alfa Aesar) with $\left(\mathrm{SiO}_{2} / \mathrm{Al}_{2} \mathrm{O}_{3}=80\right)(\mathrm{BET}=425$ $\mathrm{m}^{2} / \mathrm{g}$ ) was also used, for simplicity this catalyst is designated and labelled as HZSM-5(80).

\subsection{Catalyst Characterization}

Thermogravimetry (TGA) was performed from ambient to $600^{\circ} \mathrm{C}$ at a heating rate of 10 $\mathrm{C} / \mathrm{min}$, in a stream of dry $\mathrm{N}_{2}$ flowing at $40 \mathrm{~cm}^{3} / \mathrm{min}$, using a Perkin Elmer Thermogravimetric analyzer Pyris 1TGA. Changes in mass of the sample were recorded during the ramping operation.

Powder X-ray diffraction (XRD) experiments of the catalysts were carried out using a PANalytical X'Pert Pro X-ray diffractometer. This diffractometer is equipped with a CuK $\alpha$ X-ray source with wavelength of $1.5405 \AA$. The diffractograms were collected from $10^{\circ}$ to $89^{\circ}$. The X-ray detector was set at $40 \mathrm{kV}$ and $40 \mathrm{~mA}$. Once the scan had finished, the main peaks were selected and compared to diffraction patterns in the software library. The pattern with the highest percentage match was used.

Brunauer-Emmett-Teller (BET) analysis was performed using using a Micromeritics ASAP 2010 system. The BET surface areas and pore volumes were measured by $\mathrm{N}_{2}$ adsorption and the desorption isotherm at liquid nitrogen temperature $\left(-196{ }^{\circ} \mathrm{C}\right)$. 
The chlorine content was measured using Oxygen Flask analysis by combusting the sample in an oxygenated flask containing water, then shaking; in which chlorine dissolved in water forming $\mathrm{HCl}$, the later was titrated with $0.02 \mathrm{M} \mathrm{Hg}_{2} \mathrm{NO}_{3}$ to find $\% \mathrm{Cl}$

The total number of acidic sites (sites. $\mathrm{m}^{-2}$ ) over each catalyst were measured using the temperature programmed desorption of pyridine (TPD-pyridine) as the probe molecule. The details have been described previously $[32,33]$. This was performed using $50 \mathrm{mg}$ of the catalyst after pretreatment at $250^{\circ} \mathrm{C}$ for $2 \mathrm{~h}$ in air before the exposure to the probe molecule. 15-20 mg of pyridine-covered samples were subjected to TG analysis on heating up to $600^{\circ} \mathrm{C}$ (at $20^{\circ} \mathrm{C} / \mathrm{min}$ heating rate) in dry $\mathrm{N}_{2}$ (flow rate $=40 \mathrm{ml} / \mathrm{min}$ ). The mass loss due to desorption of pyridine from the acidic sites, was determined as a function of total surface acidity as sites. $\mathrm{g}^{-1}$ cat. The equation used to calculate the acid density site as follows:

Acid site density $=\frac{\text { moles of pyridine desorped } \times \text { Avogdro's number }(\text { sites } / \mathrm{mol})}{\text { wt. of catalyst sample }(\mathrm{g}) \times B E T\left(\mathrm{~m}^{2} / \mathrm{g}\right)}$

The determination of Lewis/Brönsted acid sites in the synthesized catalysts was performed by Diffuse Reflectance Infrared Fourier Transform (DRIFT) experiments of adsorbed pyridine using a Bruker Vertex 70 FTIR Spectrometer equipped with a liquid $\mathrm{N}_{2}$-cooled detector instrument. Samples were pre-treatment before measuring. This was achieved by outgassing at $120^{\circ} \mathrm{C}$ for $0.5 \mathrm{~h}$ under an $\mathrm{Ar}$ atmosphere. Subsequently the samples were saturated with pyridine at $50^{\circ} \mathrm{C}$ then the pysisorbed pyridine was removed by flushing with Ar gas for $0.5 \mathrm{~h}$. Fresh samples were used to record the IR background under Ar flow at $300^{\circ} \mathrm{C}$. Then, the pyridine (Py) adsorbed samples were placed in the DRIFT cell at $40^{\circ} \mathrm{C}$. The samples were heated under Ar at the flow rate of $50 \mathrm{~cm}^{3} \cdot \mathrm{min}^{-1}$ and the in situ DRIFT spectra were measured 
with a resolution of $4 \mathrm{~cm}^{-1}$ and with an accumulation of 56 scans every $30 \mathrm{~s}$. The resulted spectra after pyridine desorption were substracted from those measured before pyridine adsorption (fresh samples) in order to determine the bands relative to Lewis and Brönsted acidic sites.

Further characterization of the catalysts by scanning electron microscopy (SEM) was performed using a JEOL JSM-6500F (Field Emission Scanning Microscope) operated at 5 $\mathrm{kV}$.

\subsection{Catalyst activity}

The activity testing was carried out in an isothermal fixed-bed reactor made of stainless steel (6 mm OD). The catalyst bed consisted of 100 or $200 \mathrm{mg}(250-425 \mu \mathrm{m})$ of catalyst placed in between two plugs of quartz wool. Aera mass flow controllers were used to control the flow of He to the reactor. The liquid methanol was injected by patented Cheminert ${ }^{\circledR} \mathrm{M}$ Series liquid handling pump. A stable flow of methanol vapour to the reactor was established by passing the combined flow He and methanol through a saturator system. The evaporation chamber was kept at $150{ }^{\circ} \mathrm{C}$. In order to prevent any condensation, all of the lines were heated to $150{ }^{\circ} \mathrm{C}$. This mixture was then fed to the fixed bed reactor. The reaction conditions used 20\% methanol under atmospheric pressure and over a temperature range from 180-300 ${ }^{\circ} \mathrm{C}$. The total flow rate was $100 \mathrm{~cm}^{3} \mathrm{~min}^{-1}$. Before the reaction, the catalyst was activated in a stream of pure $\mathrm{He}$ at $325^{\circ} \mathrm{C}$ for $0.5 \mathrm{~h}$ under atmospheric pressure. Then, the methanol and He mixture was fed to the reactor and samples analysed by gas chromatography (Perkin Elmer 500) equipped with a thermal conductivity detector (TCD) and a Flame Ionisation 
Detector (FID). A Hayesep DB column was used for the separation of $\mathrm{CO}, \mathrm{CO}_{2}, \mathrm{DME}$, $\mathrm{MeOH}, \mathrm{CH}_{4}, \mathrm{C}_{2} \mathrm{H}_{4}, \mathrm{C}_{2} \mathrm{H}_{6}$, ethanol, propanol, and butanol.

The methanol conversion $\left(X_{\mathrm{MeOH}}\right)$ Eq. 5 was calculated based on the molar flow rate of methanol in the feed $\left(F_{\mathrm{MeOH}, \text { in }}\right)$ and in the outlet stream $\left(F_{\mathrm{MeOH}, \mathrm{out}}\right)$ :

$X_{\mathrm{MeOH}}=\frac{F_{\mathrm{MeOH}, \text { in }}-F_{\mathrm{MeOH}, \mathrm{out}}}{F_{\mathrm{MeOH}, \text { in }}}$

DME yield $\left(Y_{D M E}\right)$ was determined in Eq. 6 as the ratio (expressed in molar flow rate) between the actual moles of the product DME that are present in the reactor outlet stream and theoretical moles of the product DME:

$Y_{D M E}=\frac{F_{D M E, \text { actual }}}{F_{D M E, \text { theoretical }}} \times 100 \%$

DME formation rate $\left(r_{D M E}\right)$ was determined in Eq. 7 as the actual moles of the product DME that are present in the reactor outlet stream per gram catalyst:

$r_{D M E}=\frac{F_{D M E, \text { actual }}}{\text { wt.of the catalyst }} \times 100 \%$

\section{Results and Discussion}

\subsection{Catalyst characterization}

3.1.1 X-ray diffraction (XRD) analysis 
Figure (1A) displays the XRD patterns of AN120, AN300 and AN550 (a, b and c, respectively). Diffractogram (a) showed a mixture of Bayerite (JCPDS 20-11) and Gibbsite (JCPDS 33-18) in which Bayerite is the most prominent peak. As Bayerite has the highest symmetry among all $\mathrm{Al}(\mathrm{OH})_{3}$ structures it is the most thermodynamically stable phase, and thus the initially formed crystalline phase $[34,35]$. Bayerite is formed at room temperature and transforms to Gibbsite with high crystallinity. The high and sharp diffraction peak in diffractogram (a) indicates that the obtained mixture phases have a large crystalline size (see Table (1)) [33]. Diffractogram (b) showed mixture of diffraction lines that correspond to undecomposed gibbsite (JCDD 33-18) and $\eta-\mathrm{Al}_{2} \mathrm{O}_{3}$ (JCDD 04-0875). On further increasing the temperature to $500^{\circ} \mathrm{C}$, it will convert to $\eta-\mathrm{Al}_{2} \mathrm{O}_{3}$, and therefore diffractogram $\mathrm{c}, \mathrm{d}$ and $\mathrm{e}$ showed only diffraction lines belonging to $\eta-\mathrm{Al}_{2} \mathrm{O}_{3}$ (JCDD 04-0875).

Figure (1B) displays the XRD patterns of AC120, AC300, AC550, AC650 and AC750 (a, b, c, $d$, e and $f$, respectively). Diffractograms a and b showed the diffraction lines that correspond to $\gamma-\mathrm{AlO}(\mathrm{OH})$ ( JCDD 21-1307), while diffractogram $\mathrm{c}$ and $\mathrm{d}$ showed the diffractogram of $\gamma-\mathrm{Al}_{2} \mathrm{O}_{3}$ ( JCDD 10-0425). Diffractogram e showed the two diffraction lines that correspond to $\gamma-\mathrm{Al}_{2} \mathrm{O}_{3}$ (JCDD 10-0425) and $\delta-\mathrm{Al}_{2} \mathrm{O}_{3}$ (JCPDS 16-0394)[25, 36], the appearance of the new $\delta-\mathrm{Al}_{2} \mathrm{O}_{3}$ is known to affect the catalytic performance of the catalyst during the MTD reaction as will be discussed later. It is apparent from this data that the bulk structures of $\gamma$ - and $\eta-\mathrm{Al}_{2} \mathrm{O}_{3}$ are very similar to each other, and in some instances are considered to be identical $[34,37,38]$.

For all catalysts, the particle size of $\gamma-\mathrm{Al}_{2} \mathrm{O}_{3}$ increased with increasing calcination temperature which is in agreement with Seo et al. [27]. The large particle size for the AN120, i.e. the dried catalyst, is attributed to the mixture of gibbsite and bayerite as mentioned above 
(see Table (1) and Figure (2)). This then initially decreases with calcination at $300{ }^{\circ} \mathrm{C}$ and thereafter increases as in the case of the chloride precursor.

\subsubsection{TGA}

All the catalysts were subjected to TGA analysis to show the suitable temperature of calcinations $\mathrm{AC}$ and $\mathrm{AN}$ catalysts for obtaining $\gamma-\mathrm{Al}_{2} \mathrm{O}_{3}$ and $\eta-\mathrm{Al}_{2} \mathrm{O}_{3}$ phase, respectively. As seen in Figure (3)a, for AN120 catalyst, three weight loss steps corresponding to the phase transformations to $\eta-\mathrm{Al}_{2} \mathrm{O}_{3}$ are observed. The first step started at $50^{\circ} \mathrm{C}$ followed by two consecutive steps in the range $120-270^{\circ} \mathrm{C}$ and $270-500^{\circ} \mathrm{C}$. After that, the rate of weight loss during heating up to $600^{\circ} \mathrm{C}$ slowed with the formation of $\eta-\mathrm{Al}_{2} \mathrm{O}_{3}$. The total weight loss $\%$ calculated from ambient up to $600^{\circ} \mathrm{C}$ is equal to $42.3 \%$. Theoretically, the transformation of Gibbsite $\mathrm{Al}(\mathrm{OH})_{3}$ to $\eta-\mathrm{Al}_{2} \mathrm{O}_{3}$ should be associated with $34.6 \%$ weight loss. The difference in weight loss of $7.68 \%$ can be attributed to the desorption of physisorbed water[39]. For the AN300 catalyst, the percentage weight loss was $24.5 \%$. This is due to the AN300 having already undergone partial conversion from undecomposed gibbsite phase to the $\eta-\mathrm{Al}_{2} \mathrm{O}_{3}$ ) phase. Here again the difference in weight loss $9.3 \%$ can be also attributed to the desorption of physisorbed water[39] as well as dehydroxylation occurring when gibbsite transformed into $\eta-\mathrm{Al}_{2} \mathrm{O}_{3}$ [31]. For AN550 catalyst, the weight loss is $7.3 \%$ which can be attributed to the desorption of physisorbed water[39], as there is no weight loss due to the complete transformation to $\eta-\mathrm{Al}_{2} \mathrm{O}_{3}$. From Figure (3)a, the most suitable temperature to prepare $\eta$ $\mathrm{Al}_{2} \mathrm{O}_{3}$ is $550^{\circ} \mathrm{C}$ and is in good agreement with the XRD data.

Figure (3)b presents the TGA for the catalysts prepared from aluminium chloride precursor (AC120, AC300, AC370, AC550, AC650 and AC750). Here the weight loss was 29.6, 26.3, 7.7, 7.3 and 6.3, respectively. As above the XRD showed that Boehmite was formed at 120 
${ }^{\circ} \mathrm{C}$. Thus the theoretical transformation from boehmite to $\gamma-\mathrm{Al}_{2} \mathrm{O}_{3}$ should be associated with $15 \%$ weight loss, again the differences are attributed here to the desorption of physisorbed water and possible any traces of chlorine remaining in the bulk of AC catalysts (see Table (1)).

Figure (4) shows the infrared spectra of the pyridine adsorbed on AC550 (A), AN550 (B) following thermal treatment and the comparison between Py-AN550 and Py-AC550 at $100^{\circ} \mathrm{C}$ (C) in the region 1800-1100 $\mathrm{cm}^{-1}$. Spectrum (A) exhibited absorbance bands at 1222, 1445, $1488,1577,1596,1618$ and $1653 \mathrm{~cm}^{-1}$. Bands observed at 1445 and $1596 \mathrm{~cm}^{-1}$ in the spectra are attributed to the presence of hydrogen bonded pyridine adsorbed on Lewis acid sites [40, 41]. Strong Lewis bound pyridine (at 1623 and $1455 \mathrm{~cm}^{-1}$ ) and weak Lewis bound pyridine at $1575 \mathrm{~cm}^{-1}[41]$. The band observed at about $1488 \mathrm{~cm}^{-1}$ is due to adsorbed pyridine on both Lewis and Brönsted acid sites. The band at $1653 \mathrm{~cm}^{-1}$ relates to stretching and bending modes of adsorbed water[42]. The band at $1222 \mathrm{~cm}^{-1}$ is due to Al-O-Al symmetric and asymmetric bending modes[42]. From diffractogram (A), AN550 showed bands relative to Lewis acidic with strong sites at 1623 and about $1455 \mathrm{~cm}^{-1}$, a small band related to weak lewis acid sites (1575) and another small band related to Lewis and Brönsted $\left(1488 \mathrm{~cm}^{-1}\right)$ sites. It is clear from DRIFTs spectra that the Lewis acidic sites are responsible for the acidity in AN550 ( $\eta$ $\left.\mathrm{Al}_{2} \mathrm{O}_{3}\right)$ and $\mathrm{AC} 550\left(\gamma-\mathrm{Al}_{2} \mathrm{O}_{3}\right)$ which is in agreement with Seo et al. results[27].

Spectrum (B) exhibited the same features to that of AN550, except that the intensity of the absorption bands in AC550 are lower than that of AN550, which is clear in spectrum (C). DRIFT spectra (C) give clear evidence that AN550 is higher acidity than AC550. 
Figure (5) shows the SEM images of AN550 and AC550. As seen from these there is a difference in the morphology of the particles. Here the AN550 (Figure (3)a) tends to consist ef spherical particles. Clearly the AC550 produces a much smoother surface. It can thus be concluded from the SEM that the surface roughness is very different between the AN550 and AC550 catalysts.

\subsection{Catalyst activity}

Figure (6) shows the effect of calcination temperature of AN and AC catalysts for reactions carried out over the temperature range $180-300{ }^{\circ} \mathrm{C}$. It is clear from Figure (6)a that for each reaction temperature, above a minimum of approximately $200{ }^{\circ} \mathrm{C}$, that the methanol conversion increased until a maximum at calcination temperature of $650{ }^{\circ} \mathrm{C}$, after which it decreases sharply. The particle size of $\gamma-\mathrm{Al}_{2} \mathrm{O}_{3}$ increased as the calcination temperature increased. In the temperature range from $300{ }^{\circ} \mathrm{C}$ to $650{ }^{\circ} \mathrm{C}$, the particle size of the samples was comparable (see Table (1)). As the temperature increased to $750{ }^{\circ} \mathrm{C}$, the change was significant $(15.8 \%)$. This change was accompanied with a decrease in acid site density of $6.7 \%$ and the presence of new $\delta-\mathrm{Al}_{2} \mathrm{O}_{3}$ phase[25] with the $\gamma-\mathrm{Al}_{2} \mathrm{O}_{3}$ (see Figure (1)B graph e), it may cause a sharp decrease in catalytic activity of AN750 as shown in Figure (4)a. Therefore as expected the properties of the acid sites and their density within the alumina change with the calcination temperature (see Table (1)). It can be seen from Figure (6)b that for each reaction temperature the methanol conversion increased until a maximum was found between 550 and $650{ }^{\circ} \mathrm{C}$. This maximum is less clearly defined than in the case of the AC catalysts. The decrease of activity at calcination temperature of $750{ }^{\circ} \mathrm{C}$ may be attributed to the structure of $\eta-\mathrm{Al}_{2} \mathrm{O}_{3}$ calcined at $750{ }^{\circ} \mathrm{C}$ which partially collapsed resulting in a decrease in acid site density[27] and an associated decrease in catalytic activity. 
Figure (7) shows the effect of temperature on the activity of solid acid catalysts prepared using different aluminium precursors. But as shown in the Figure (7) a, as the temperature increased the activity increased for all catalysts in the following sequence: AN650 > AN550 $>$ AN300 $>$ AN750 $>$ AN120. Clearly the thermodynamic equilibrium conversion for AN300, AN550 and AN650 is obtained at temperatures greater than $275{ }^{\circ} \mathrm{C}$. Given the equilibrium constraints the conversion of methanol does not exceed $86.5 \%$ and thus the maximum conversion of methanol is limited under the reaction conditions $\left(300{ }^{\circ} \mathrm{C}\right)$ employed. It can be seen from Figure (7) $b$ that all catalysts exhibited low activity at reaction temperatures below $200{ }^{\circ} \mathrm{C}$ regardless the calcinations temperature, and is attributed to the low activity of alumina at such temperatures. Fu et al. [16] and Jiang et al. [11] studied the effect of temperature on the activity of $\gamma-\mathrm{Al}_{2} \mathrm{O}_{3}$ for dehydration of methanol to DME. They found that $\gamma-\mathrm{Al}_{2} \mathrm{O}_{3}$ exhibited low activity at temperatures below $300{ }^{\circ} \mathrm{C}$. As the reaction temperature increased, the methanol conversion increased for all catalysts in the following sequence: AC650 $>$ AC550 $>$ AC750 $>A C 300>A C 120$. However it is clear from Figure (7) a and $b$ that the most active catalysts at all reaction temperatures are AN550 and AN650 from aluminium nitrate precursor and AC650 from aluminium chloride precursor.

As shown in Figure (7), AN catalysts are higher in activity than AC catalysts at the same calcination temperature. For instance, AN550 $\left(\eta-\mathrm{Al}_{2} \mathrm{O}_{3}\right)$ and $\mathrm{AC} 550\left(\gamma-\mathrm{Al}_{2} \mathrm{O}_{3}\right)$ were calcined at $550{ }^{\circ} \mathrm{C}$ however there are significant differences in methanol conversion especially at reaction temperatures higher than $200{ }^{\circ} \mathrm{C}$. Such differences could be attributed to differences in surface area, total acid sites, acid density, morphology and structure. From Table (1), AN300 and AC300 have acid site densities of 6.3 and 3.5 sites $/ \mathrm{m}^{2}$, respectively which is in fact higher than that of AN550 and AC550 i.e. 3.8 and 2.5 sites $/ \mathrm{m}^{2}$, respectively. From XRD (Figure (1)), AN300 has a mixture of $\left(\eta-\mathrm{Al}_{2} \mathrm{O}_{3}\right.$ and gibbsite) phases while AC300 has only 
boehmite phase. On the other hand AN550 and $\mathrm{AC} 550$ have the $\eta-\mathrm{Al}_{2} \mathrm{O}_{3}$ and $\gamma-\mathrm{Al}_{2} \mathrm{O}_{3}$ phase, respectively. This means that different $\mathrm{Al}_{2} \mathrm{O}_{3}$ phase can be formed when starting with different precursors. Such significant differences in activity between AN catalysts and AC catalysts, may be attributed to the structure $\gamma-\mathrm{Al}_{2} \mathrm{O}_{3}$ which possessed almost hexagonally formed crystallites with an exposed surface of (110) planes preferentially whereas $\eta-\mathrm{Al}_{2} \mathrm{O}_{3}$ possessed relatively large particles, and the preferentially exposed surfaces correspond to the (111) crystallographic planes.[27]

Furthermore given the relative difference in activities between the two precursors and their relative similarity in terms of surface area etc., for example, AN550 has higher DME formation rate than AC550 catalyst for all temperature ranges as shown in Figure (8)a and higher DME yield (see Table (1)), this suggests that some poisoning of catalyst sites due to residual chloride may be responsible.

Figure (8)a shows the effect of reaction temperature on the DME formation rate (calculated based on Eq. (7)) over the produced AN550, AC550, a commercial $\gamma-\mathrm{Al}_{2} \mathrm{O}_{3}$ and a commercial HZSM-5(80). The most suitable dehydration catalysts should have a sufficient activity to generate the desired product but also prevent the production of by-products through further DME dehydration. In this case the selectivity to DME was almost $100 \%$ for all catalysts under the conditions used here. It can be seen that at low temperatures ranging from 180 to 275, that the HZSM-5(80) has a higher reaction rate but as the temperature is increased to 275 the activity of AN550 catalyst increased is now higher than that of the HZSM-5 (80). From Figure (7), the conversion of AC550 at $250{ }^{\circ} \mathrm{C}$ is $35.2 \%$ and from Figure (8) the conversion of $\gamma-\mathrm{Al}_{2} \mathrm{O}_{3}$ is around $37 \%$. This confirms that $\mathrm{AC} 550$ and $\gamma-\mathrm{Al}_{2} \mathrm{O}_{3}$ has the same structure. 
Figure (8)b shows the methanol conversion as a function of time on stream over different acid catalysts at $250{ }^{\circ} \mathrm{C}$. As before it is clear that the activity of catalyst increases in the following sequence: $\mathrm{H}-\mathrm{ZSM}-5(80)>\mathrm{AN} 550>\mathrm{AN} 650>\gamma-\mathrm{Al}_{2} \mathrm{O}_{3}$. All catalysts were stable over the reaction time. The methanol conversion over HZSM-5(80) zeolite decreased slightly from $85 \%$ to $82 \%$, while AN550 decreased from $77 \%$ to $71.3 \%$ and for $\gamma-\mathrm{Al}_{2} \mathrm{O}_{3}$ decreased from $41 \%$ to $35 \%$ during a dehydration period of $70 \mathrm{~h}$. This is likely attributed to coke formation over HZSM-5(80) [43] and to water adsorption on $\gamma-\mathrm{Al}_{2} \mathrm{O}_{3}$ and AN550. The result for HZSM-5(80) echoed an earlier finding by Abu-Dahrieh et al.[43], which showed that coke formation over HZSM-5(80) is responsible for this deactivation. Although initially AN650 has a similar activity to AN550 it is less stable, as seen in the methanol conversion which decreased from $80 \%$ to $52 \%$. This may be attributed to the appearance of although this could not be confirmed by the XRD (not shown) used herein[27]. From this it can seen that the activity of AN550 is two times the activity of commercial $\gamma-\mathrm{Al}_{2} \mathrm{O}_{3}$ and around $87 \%$ of HZSM-5 (80) activity.

Figure (9) shows the effect of space velocity on the activity of AN550. From the experimental data AN550 is active enough to give the equilibrium conversion of methanol at the reaction temperatures above $260{ }^{\circ} \mathrm{C}$. From this it can be seen that an increase in catalyst mass leads to an increase in reaction rate where it can be observed that a linear relationship between catalyst mass and DME yield is obtained. Further increases in catalyst mass would therefore allow for higher conversions although this would introduce additional complications such as pressure drop. 


\section{Conclusions}

Herein different acid catalysts were prepared using two precursors with different calcination temperatures during the production of DME from methanol. From the X-ray diffraction (XRD) pattern, different transition states of alumina were detected based on this calcination temperature. The boehmite was changed to $\gamma-\mathrm{Al}_{2} \mathrm{O}_{3}$ at $550{ }^{\circ} \mathrm{C}$, and the bayerite was completely changed to $\eta-\mathrm{Al}_{2} \mathrm{O}_{3}$ when calcined at $550{ }^{\circ} \mathrm{C}$. Among these catalysts that produced using the alumina nitrate precursor and calcined at $550{ }^{\circ} \mathrm{C}$ i.e. AN550 showed the highest catalytic performance under the reaction conditions $\left(\mathrm{T}=180-300{ }^{\circ} \mathrm{C}, \mathrm{WHSV}=12.1 \mathrm{~h}^{-}\right.$ ${ }^{1}$ ), compared it with AC550 and commercial $\gamma-\mathrm{Al}_{2} \mathrm{O}_{3}$ and higher than commercial zeolite HZSM-5 (80) for temperatures above $275{ }^{\circ} \mathrm{C}$. A comparison showed that this material had double the activity of the (commercial $\gamma-\mathrm{Al}_{2} \mathrm{O}_{3}$ and AC550) and $87 \%$ activity of commercial HZSM-5 (80) at $250^{\circ} \mathrm{C}$. The acid site density over catalysts changed with the calcination temperature. In the methanol dehydration, the acid site density affected catalytic performance among the catalysts with alumina phase structure.It is thus recommended that AN550 ( $\eta$ $\mathrm{Al}_{2} \mathrm{O}_{3}$ ) is the most suitable catalyst for using in the production of DME from methanol.

\section{References}

[1] C. Paddock, Medical News Today 2012.

[2] F. Yaripour, F. Baghaei, I. Schmidt, J. Perregaard, Catalysis Communications. 6 (2005) 147-152.

[3] Z. Zhu, D.K. Li, J. Liu, Y.J. Wei, S.H. Liu, Applied Thermal Engineering. 35 (2012) $9-14$.

[4] R. Ladera, E. Finocchio, S. Rojas, J.L.G. Fierro, M. Ojeda, Catalysis Today (2012).

[5] Q. Tang, H. Xu, Y. Zheng, J. Wang, H. Li, J. Zhang, Applied Catalysis A: General. 413â€“4414 (2012) 36-42.

[6] A.R. Keshavarz, M. Rezaei, F. Yaripour, Journal of Natural Gas Chemistry. 20 (2011) 334-338. 
[7] F. Raoof, M. Taghizadeh, A. Eliassi, F. Yaripour, Fuel. 87 (2008) 2967-2971.

[8] J. Khom-in, P. Praserthdam, J. Panpranot, O. Mekasuwandumrong, Catalysis Communications. 9 (2008) 1955-1958.

[9] M. Mollavali, F. Yaripour, S. Mohammadi-Jam, H. Atashi, Fuel Processing Technology. 90 (2009) 1093-1098.

[10] D. Liu, C. Yao, J. Zhang, D. Fang, D. Chen, Fuel. 90 (2011) 1738-1742.

[11] S. Jiang, J.-S. Hwang, T. Jin, T. Cai, W. Cho, Y.s. Baek, S.-E. Park, Bulletin of the Korean Chemical Society. 25 (2004) 185-189.

[12] M.R. Sun Kou, S. Mendioroz, P. Salerno, V. Munoz, Applied Catalysis A: General. 240 (2003) 273-285.

[13] K. Lertjiamratn, P. Praserthdam, M. Arai, J. Panpranot, Applied Catalysis A: General. 378 (2010) 119-123.

[14] F. Yaripour, F. Baghaei, I. Schmidt, J. Perregaard, Catalysis Communications. 6 (2005) 542-549.

[15] J. Fei, Z. Hou, B. Zhu, H. Lou, X. Zheng, Applied Catalysis A: General. 304 (2006) 49-54.

[16] Y. Fu, T. Hong, J. Chen, A. Auroux, J. Shen, Thermochimica Acta. 434 (2005) 22-26.

[17] N. Khandan, M. Kazemeini, M. Aghaziarati, Applied Catalysis A: General. 349 (2008) 6-12.

[18] F.S. Ramos, A.M.D.d. Farias, L.E.P. Borges, J.L. Monteiro, M.A. Fraga, E.F. SousaAguiar, L.G. Appel, Catalysis Today. 101 (2005) 39-44.

[19] M. Xu, J.H. Lunsford, D.W. Goodman, A. Bhattacharyya, Applied Catalysis A: General. 149 (1997) 289-301.

[20] K.C. Tokay, T. Dogu, G. Dogu, Chemical Engineering Journal. 184 (2012) 278-285.

[21] G.R. Moradi, F. Yaripour, P. Vale-Sheyda, Fuel Processing Technology. 91 (2009) 461-468.

[22] V. Vishwanathan, K.-W. Jun, J.-W. Kim, H.-S. Roh, Applied Catalysis A: General. 276 (2004) 251-255.

[23] M.S. Ghamsari, Z.A.S. Mahzar, S. Radiman, A.M.A. Hamid, S.R. Khalilabad, Materials Letters. 72 (2012) 32-35.

[24] G.-f. Fu, J. Wang, J. Kang, Transactions of Nonferrous Metals Society of China. 18 (2008) 743-748.

[25] Y.G. Wang, C. Suryanarayana, L.A. An, Journal of the American Ceramic Society. 88 (2005) 780-783. 
[26] L. Liu, W. Huang, Z.-h. Gao, L.-h. Yin, Journal of Industrial and Engineering Chemistry. 18 (2012) 123-127.

[27] C.W. Seo, K.D. Jung, K.Y. Lee, K.S. Yoo, Industrial \& Engineering Chemistry Research. 47 (2008) 6573-6578.

[28] M. Zabeti, W.M.A. Wan Daud, M.K. Aroua, Fuel Processing Technology. 90 (2009) 770-777.

[29] H. Knozinger, P. Ratnasamy, Catalysis Reviews-Science and Engineering. 17 (1978) $31-70$.

[30] V. Vatanpour, S.S. Madaeni, L. Rajabi, S. Zinadini, A.A. Derakhshan, Journal of Membrane Science. 401-402 132-143.

[31] Q. Yang, Bull. Mater. Sci. 34 (2011) 239-244.

[32] S.A. Halawy, Chemical Monthly. 134 (2003) 371-380.

[33] G.A.H. Mekhemer, S.A. Halawy, M.A. Mohamed, M.I. Zaki, J. Phys. Chem. B. 108 (2004) 13379-13386.

[34] W.Q. Jiao, M.B. Yue, Y.M. Wang, M.-Y. He, Microporous and Mesoporous Materials. 147 (2012) 167-177.

[35] K. Wefers, C. Misra, Alcoa Technical Paper No. 19, Revised (1987).

[36] P.S. Santos, H.S. Santos, S.P. Toledo, Materials Research. 3 (2000) 104-114.

[37] A.L. Dragoo, J.J. Diamond, Journal of the American Ceramic Society. 50 (1967) 568574.

[38] K. Sohlberg, S.T. Pantelides, S.J. Pennycook, Journal of the American Chemical Society 123 (2001) 26-29.

[39] H.S. Potdar, K.-W. Jun, J.W. Bae, S.-M. Kim, Y.-J. Lee, Applied Catalysis A: General. 321 (2007) 109-116.

[40] J. Aguado, J.M. Escola, M.C. Castro, B. Paredes, Applied Catalysis A: General. 284 (2005) 47-57.

[41] B. Chakraborty, B. Viswanathan, Catalysis Today. 49 (1999) 253-260.

[42] H.S. Potdar, K.-W. Jun, J.W. Bae, S.-M. Kim, Y.-J. Lee, Applied Catalysis A: General. 321 (2007) 109-116.

[43] J. Abu-Dahrieh, D. Rooney, A. Goguet, Y. Saih, Chemical Engineering Journal. 203 (2012) 201-211. 
Table (1): Properties of the catalysts.

\begin{tabular}{|c|c|c|c|c|c|c|c|}
\hline \multirow{2}{*}{$\begin{array}{l}\text { Catalyst } \\
\text { Abbreviation }\end{array}$} & \multirow{2}{*}{$\begin{array}{c}\text { Chlorine } \\
\%\end{array}$} & \multicolumn{2}{|c|}{ Surface area } & \multirow{2}{*}{$\begin{array}{c}\text { Particle } \\
\text { size } \\
\text { nm }\end{array}$} & \multirow{2}{*}{$\begin{array}{c}\text { Total } \\
\text { acidity }^{1} \text {, } \\
\text { A } \\
\text { (sites/g) }\end{array}$} & \multirow{2}{*}{$\begin{array}{l}\text { Acid site } \\
\text { density }^{2)} \text {, } \\
\text { B } \\
\left(\text { sites } / \mathbf{m}^{2}\right)\end{array}$} & \multirow{2}{*}{$\begin{array}{c}\text { DME } \\
\text { Yield } \\
\%^{3)}\end{array}$} \\
\hline & & $\begin{array}{l}S_{\text {BET }} \\
\mathrm{m}^{2} / \mathrm{g}\end{array}$ & $\begin{array}{c}\text { Pore } \\
\text { volume } \\
\mathrm{cm}^{3} / \mathrm{g}\end{array}$ & & & & \\
\hline AN120 & Nil & 369 & 0.15 & 18.1 & -- & -- & 44.4 \\
\hline AN300 & Nil & 300 & 0.2 & 4.3 & 18.75 & 6.3 & 72.7 \\
\hline AN550 & Nil & 223 & 0.5 & 5.5 & 8.56 & 3.8 & 86.9 \\
\hline AN650 & Nil & 189 & 0.41 & 6.4 & 7.02 & 3.7 & 88 \\
\hline AN750 & Nil & 169 & 0.31 & 8 & 4.83 & 2.9 & 64.1 \\
\hline $\mathrm{AC} 120$ & 1.2 & 378 & 0.20 & 3.1 & -- & -- & 10.7 \\
\hline $\mathrm{AC} 300$ & 0.8 & 308 & 0.22 & 3.1 & 11.05 & 3.5 & 14.2 \\
\hline AC550 & 0.38 & 278 & 0.35 & 3.7 & 6.91 & 2.5 & 43 \\
\hline AC650 & 0.2 & 230 & 0.31 & 3.8 & 5.52 & 2.4 & 60.3 \\
\hline AC750 & 0.15 & 187 & 0.30 & 4.4 & 4.20 & 2.24 & 40.4 \\
\hline$\gamma-\mathrm{Al}_{2} \mathrm{O}_{3}$ & Nil & 117 & 0.42 & 5.9 & 4.11 & 3.51 & 40 \\
\hline HZSM-5(80) & Nil & 425 & 0.17 & 2.9 & 9.82 & 2.31 & 89 \\
\hline
\end{tabular}

1): Total acidity $=\mathrm{A} \times 10^{20}$

2): Acid site density $=\mathrm{B} \times 10^{18}$

3): $\mathrm{T}=250{ }^{\circ} \mathrm{C}$; He flow rate $=80 \mathrm{ml} / \mathrm{min}$; WHSV: $12.1 \mathrm{~h}^{-1}$ 


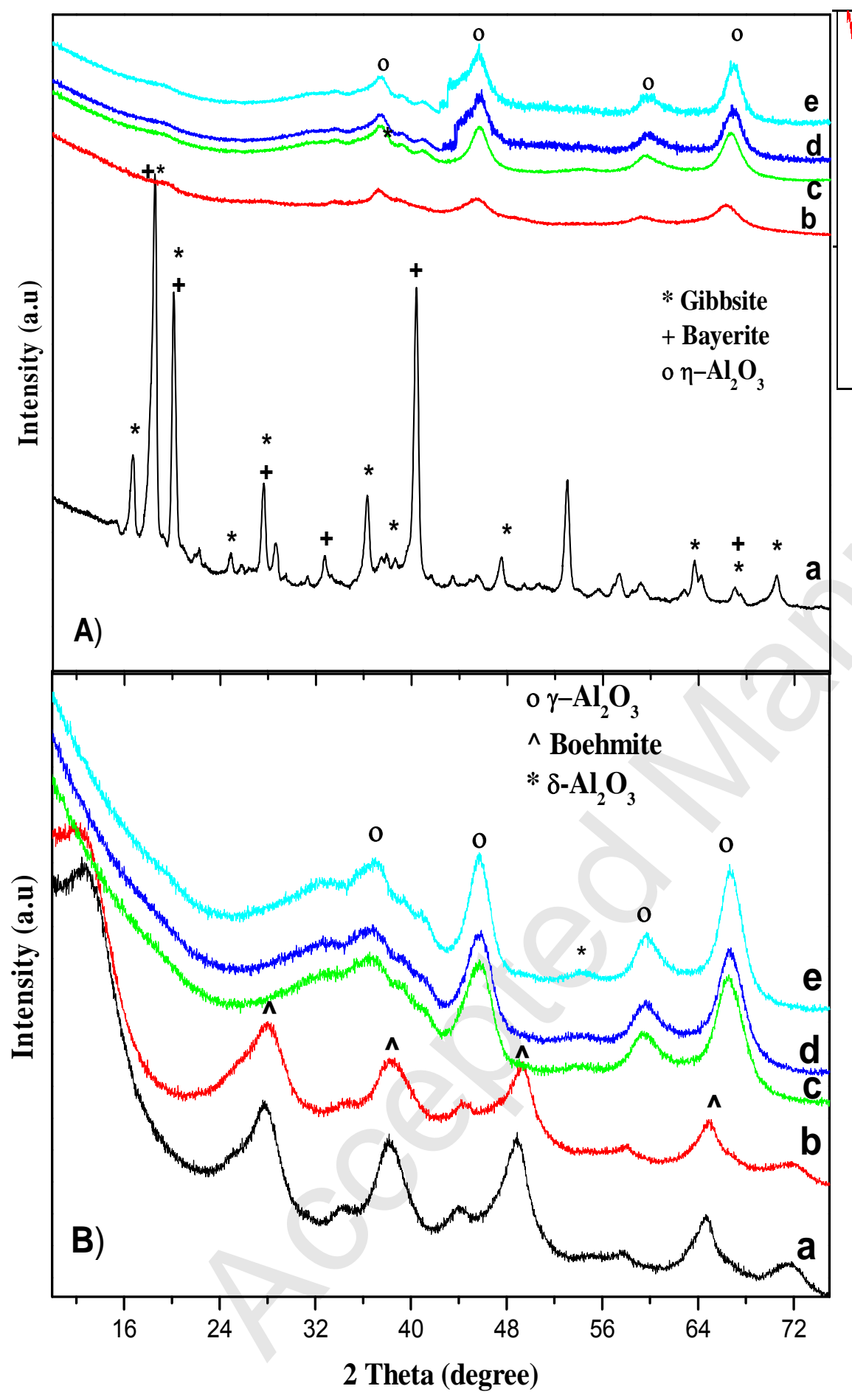

Figure (1): A): XRD patterns of different acid catalysts prepared from Aluminium nitrate precursor, (a AN120, (b AN300, (c AN550, (d AN650 and (e AN750; B): XRD patterns of different acid catalysts prepared from Aluminium chloride precursor, (a AC120, (b AC300, (c AC550, (d AC650 and (e AC750. 


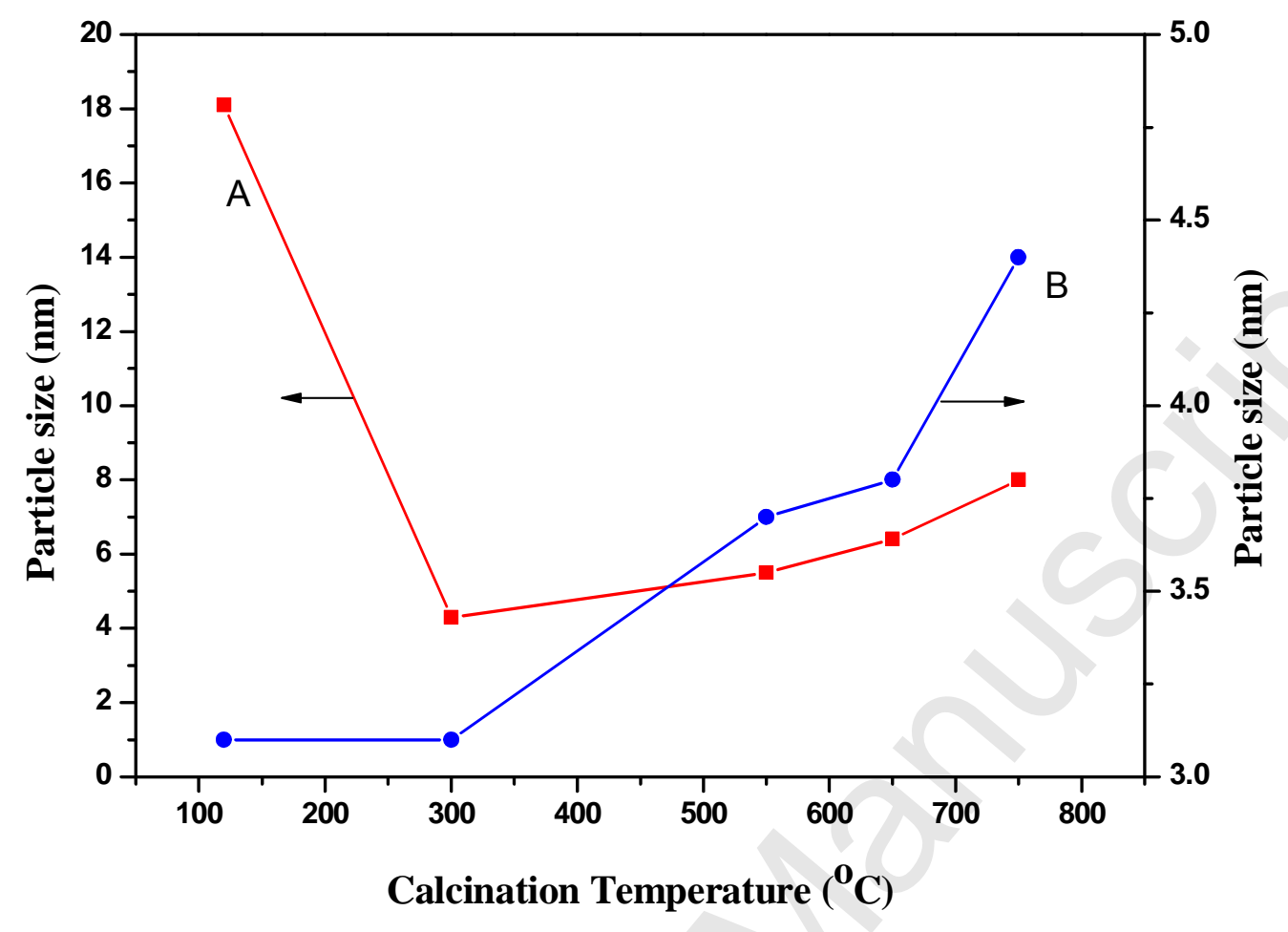

Figure (2): The effect of calcination on particle size for AN samples (A) and AC samples (B). 

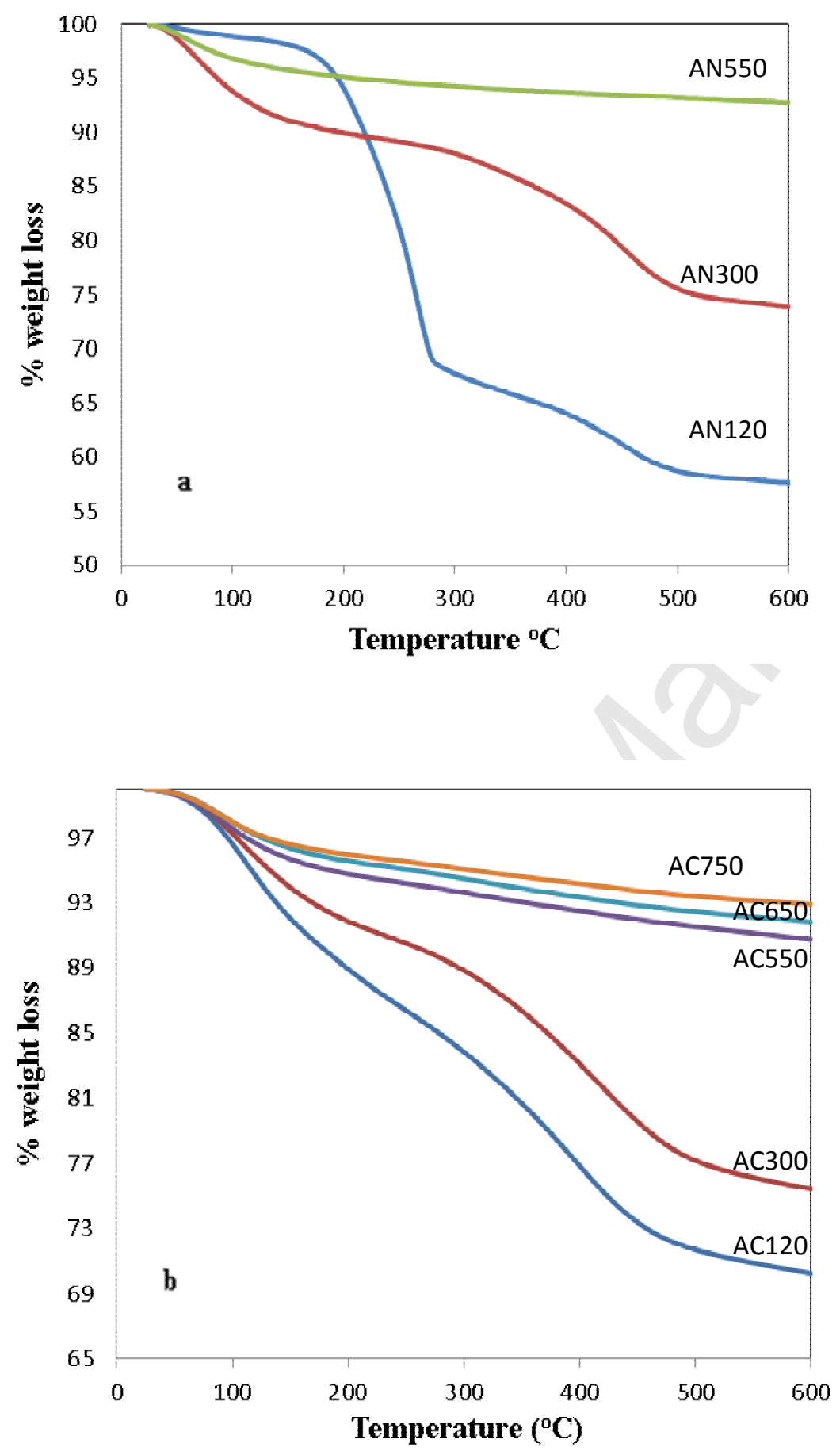

Figure (3): TGA curves for the catalysts in $\mathrm{N}_{2}$ atmosphere with heating rate $10^{\circ} \mathrm{C} / \mathrm{min}$. 


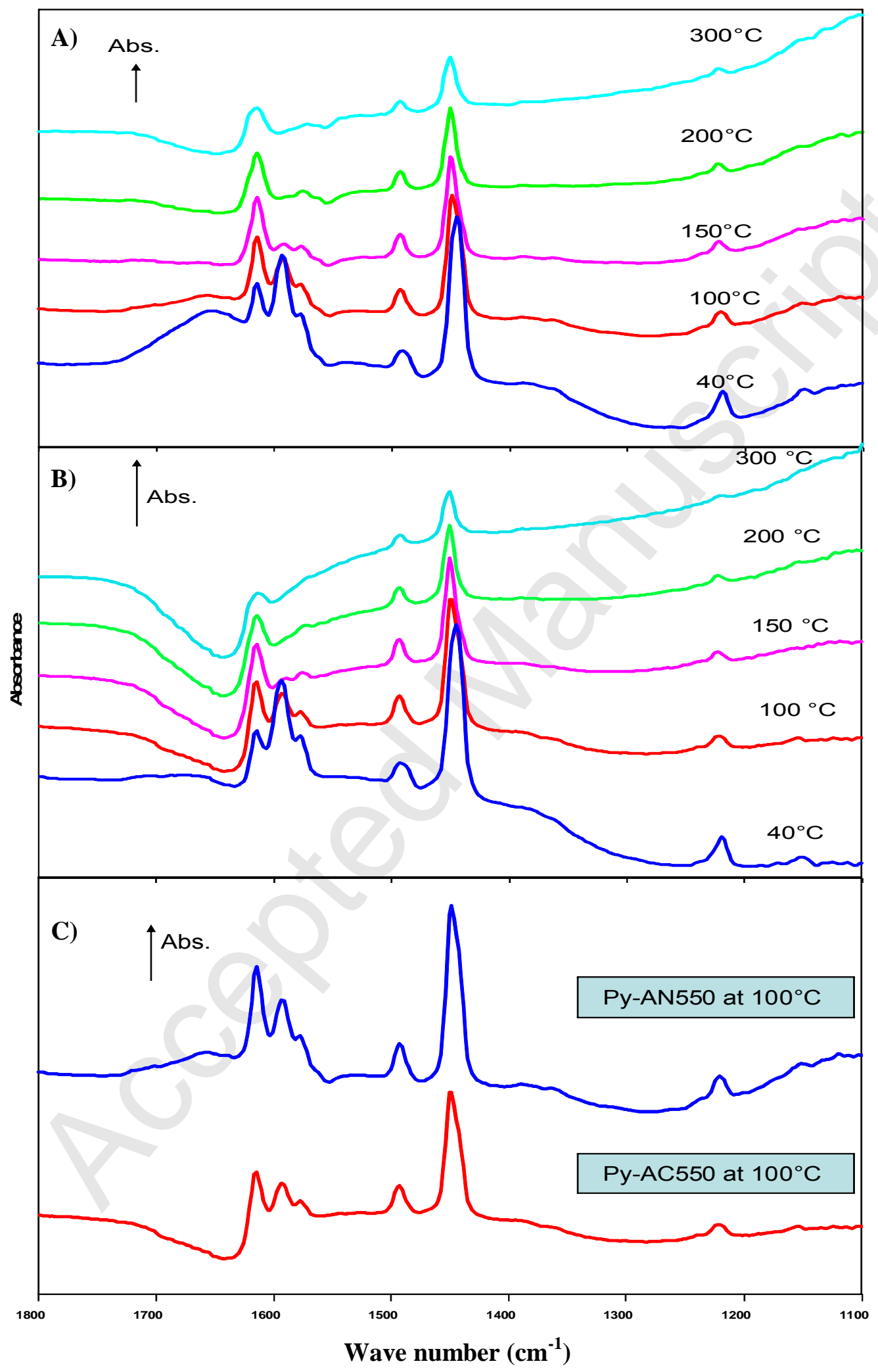

Figure (4): In situ DRIFTS spectra of pyridine desorption pyridine adsorbed on AC550 (A), AN550 (B) following thermal treatment and the comparison between pyridine -AN550 and pyridine -AC550 at $100^{\circ} \mathrm{C}(\mathrm{C})$ in the region $1800-1100 \mathrm{~cm}^{-1}$. 
(a)
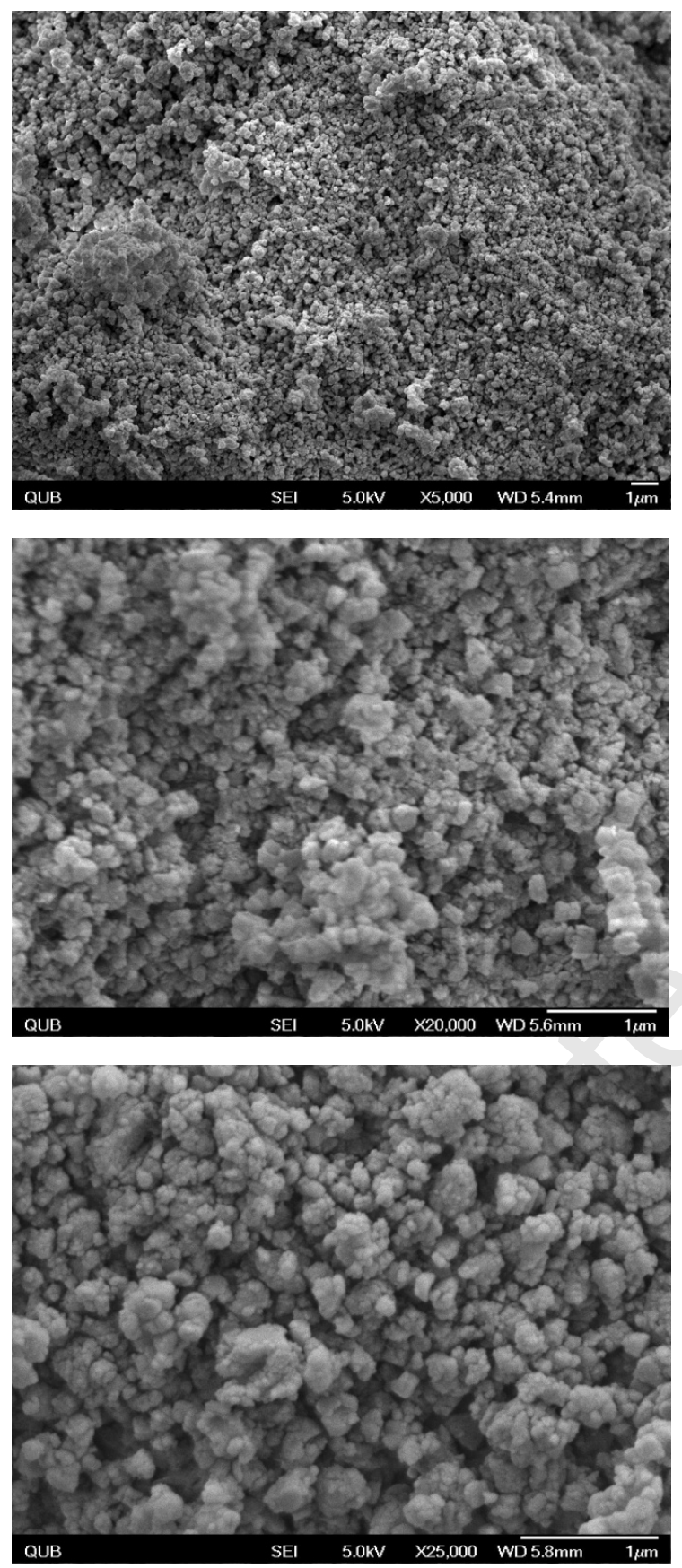

(b)
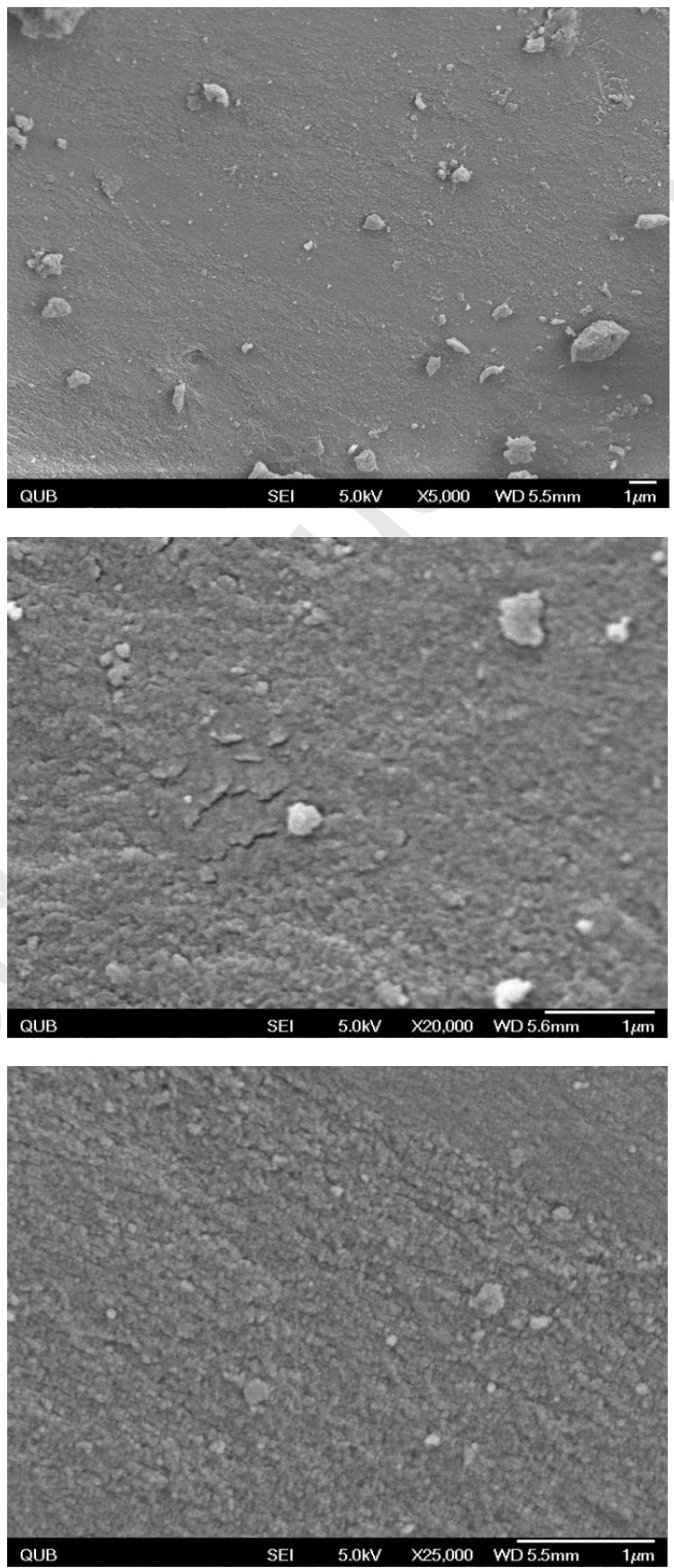

Figure (5): Representative SEM micrographs of (a) AN550 and (b) AC550 with magnification 5000, 20000 and 25000, respectively. 

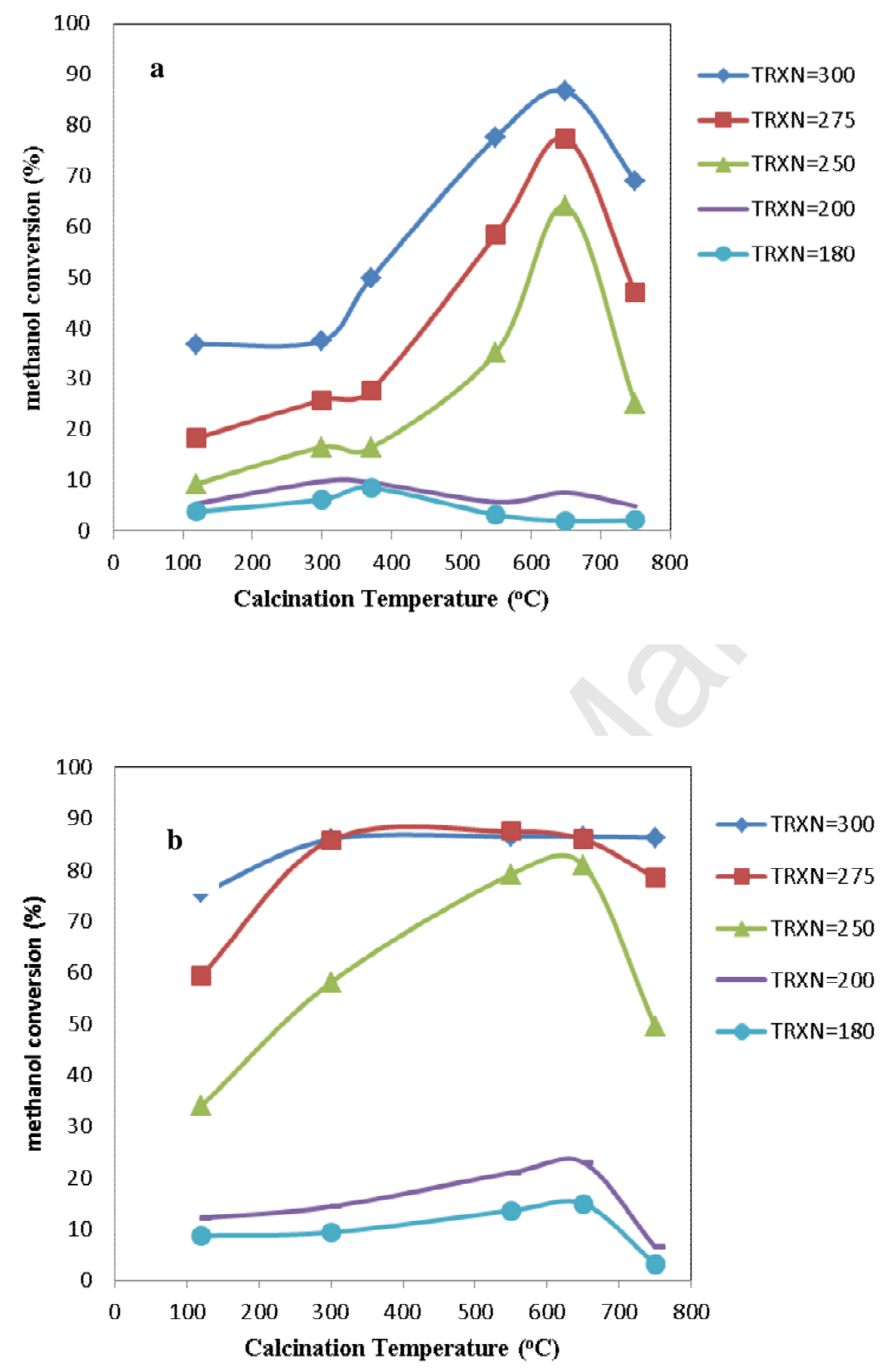

Figure (6): Effect of calcination temperature on methanol conversion over catalysts; a: (prepared from AC precursor); b: (prepared from AN precursor); at different reaction 
temperature. $\left(\mathrm{T}=180-300{ }^{\circ} \mathrm{C}\right.$; catalyst weight $=200 \mathrm{mg}$; He flow rate $=80 \mathrm{ml} / \mathrm{min}$; WHSV: $\left.12.1 \mathrm{~h}^{-1}\right)$.
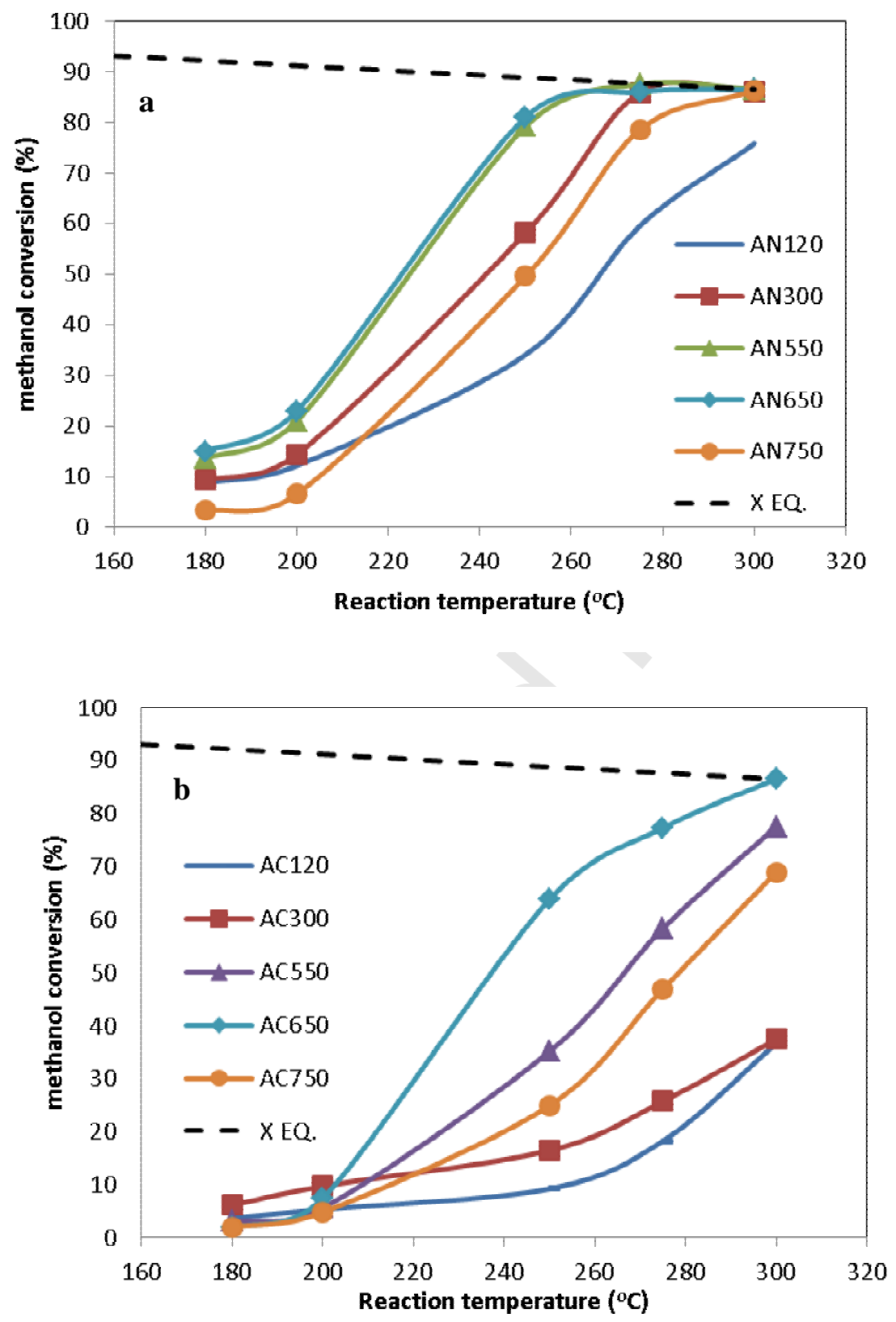

Figure (7): Effect of reaction temperature on methanol dehydration to DME over catalysts prepared using different precursor at different calcination temperature. a: aluminium nitrate 
and $\mathrm{b}$ : aluminium chloride. $\left(\mathrm{T}=180-300{ }^{\circ} \mathrm{C}\right.$; catalyst weight $=200 \mathrm{mg}$; He flow rate $=80$ $\mathrm{ml} / \mathrm{min}$; WHSV: $\left.12.1 \mathrm{~h}^{-1}\right)$.
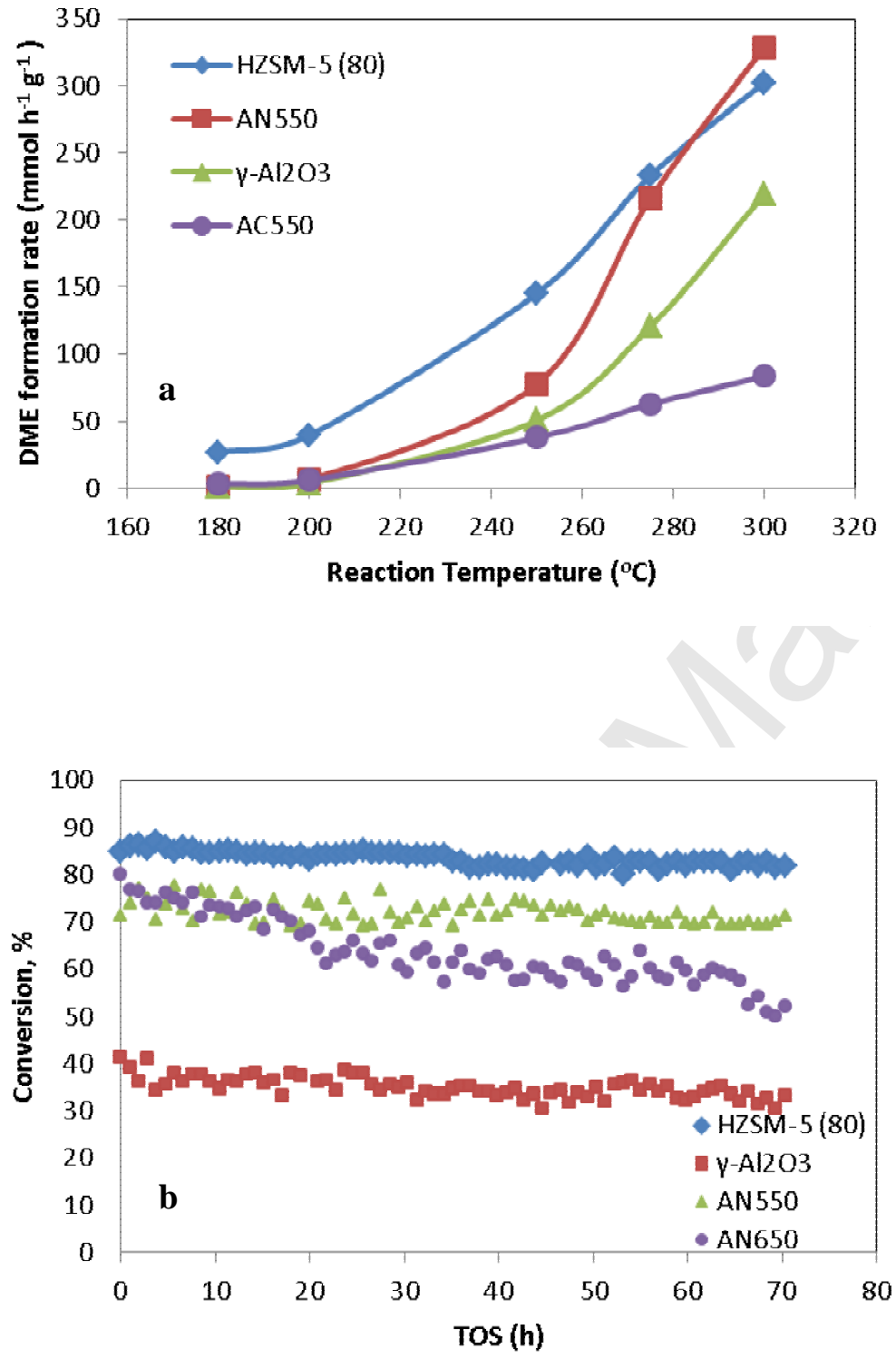

Figure (8): a: Effect of reaction temperature on DME formation rate over catalysts (AN550, commercial $\gamma-\mathrm{Al}_{2} \mathrm{O}_{3}$ and commercial HZSM-5(80)); b: $\mathrm{MeOH}$ conversion with time on stream over HZSM-5 (80), commercial $\gamma-\mathrm{Al}_{2} \mathrm{O}_{3}$, AN550 and AN650. $\left(\mathrm{T}=250{ }^{\circ} \mathrm{C}\right.$; catalyst weight $=200 \mathrm{mg}$; He flow rate $=80 \mathrm{ml} / \mathrm{min} ;$ WHSV: $12.1 \mathrm{~h}^{-1}$ ). 


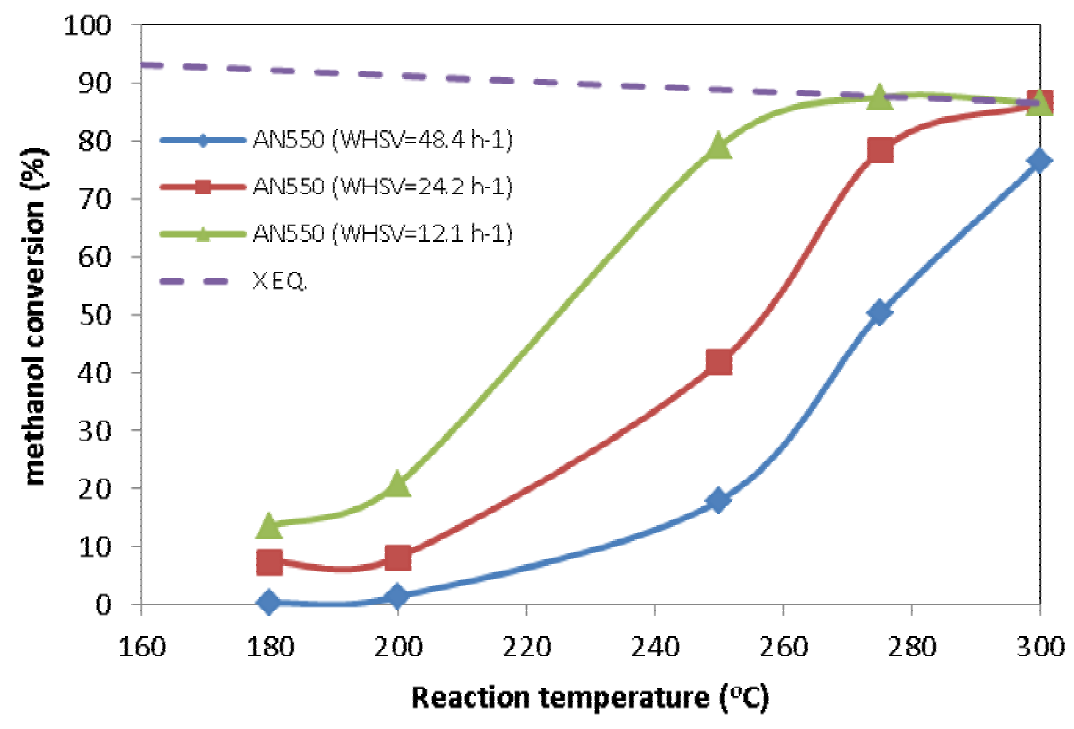

Figure (9): Effect of space velocity of AN550 on methanol conversion to DME at different reaction temperature. (He flow rate $=80 \mathrm{ml} / \mathrm{min}$ ). 